DOI: 10.17707/AgricultForest.62.1.03

\begin{abstract}
Hitoshi YAMAMOTO, Hiromu OKAZAWA, Yasushi TAKEUCHI, Machito MIHARA ${ }^{I}$
\end{abstract}

\title{
EFFECTIVENESS OF CLINKER ASH IN REMOVING NITRATE NITROGEN FROM AGRICULTURAL WASTE WATER
}

\section{SUMMARY}

Clinker ash is a type of coal ash generated by thermal power plants. At present, reuse of coal ash has been required, because large amounts of coal ash are generated by coal-fired power plants every year. In this study, the ability of clinker ash to purify nitrogen pollution water was evaluated by using two kind of water, which was contaminated with nitrate nitrogen and ammonium nitrogen.

Four kind of clinker ash, which differ particle size distribution were used as specimens for the column experiment. Each type of clinker ash was placed in a cylindrical column. Then, we prepared two kind of test water contaminated with nitrate nitrogen $(10 \mathrm{mg} / \mathrm{L})$ and ammonium nitrogen $(10$ $\mathrm{mg} / \mathrm{L})$. Two-test water was filtered through each column at $200 \mathrm{~mL} /$ day for 66 days. The nitrogen concentration of the water that flowed out of the column was measured.

The column experiment confirmed that nitrogen is removed by nitrogen adsorption of clinker ash. Namely, it was clarified that clinker ash has a great capacity to adsorb NO3-N and NH4-N. It was also found that fine-particle clinker ash is able to adsorb large amount of nitrogen. As the results, we concluded that clinker ash could be useful for nitrogen adsorbent of agricultural wastewater treatment. However, it is necessary to pay close attention to the particle size distribution of clinker ash when developing a water purification system using clinker ash.

Keywords: Clinker ash, Nitrate-nitrogen, Ammonium-nitrogen, Adsorption, Wastewater

\section{INTRODUCTION}

Nitrogen is an essential component for food and feed production. On the other hand, excessive nitrogen application on farmland is used around the world. Excessive use of nitrogen can lead to nitrogen discharge from farmland to river (Okazawa, et al. 2010 and Yoshinaga, et al. 2007) and to serious problems related to human health and ecosystem vulnerability such as acidification of soil

\footnotetext{
1 Hiromu Okazawa, Yasushi Takeuchi, Machito Mihara, (corresponding author: h1okazaw@nodai.ac.jp),Faculty of Regional Environment Science, Tokyo University of Agriculture, JAPAN, Hitoshi Yamamoto, Shizuoka Prefectural Government, Shizuoka prefecture, JAPAN

Paper presented at the $6^{\text {th }}$ International Scientific Agricultural Symposium "AGROSYM 2015".

Notes: The authors declare that they have no conflicts of interest. Authorship Form signed online.
} 
and eutrophication of coastal system (Mosier et al, 2004). Therefore, if it were possible to construct a nitrogen mitigation system in which the nitrogen running off of farmland is captured, then agriculture with environmental burdens would be possible.

Coal is a vital role for global energy security. The coal that is used for thermal power plants is a solid, which makes it safer to transport than LNG (Liquefied Natural Gas), and it is more economical than LNG because of its abundant reserves. At present, about $40 \%$ of the world's energy is generated by coal-fired power plants (World coal association, 2015). In Japan, 20\% of electricity is provided by coal-fired thermal generation. 220 million $\mathrm{kg}$ clinker ash, which is a kind of coal ash, emits from coal-fired power plant every year. Clinker ash was specified as an item that should be recycled, since the Revised Recycling Law of Japan established in 2001. However, most of it ends up in landfills without recycle; thus recycling of clinker ash is an important environmental issue (JETA, 2005).

Clinker ash has been reported to be able to purify water contaminated with ammonium nitrogen. Because of clinker ash is a numerous pore material; it has good potential as a water purification material (Yamamoto et al., 2011). Okazawa and Fujikawa (2014) reported that clinker ash has a great capacity to adsorb NH4-N. It was also found that fine-grained clinker ash is able to adsorb large amount of nitrogen, which can be used by plants as compost. However, nothing is the experimental result relating to nitrate nitrogen contamination. In this study, the ability of clinker ash to purify water was evaluated in laboratory experiments using the cylindrical columns with high concentration nitrate nitrogen solution water and ammonium nitrogen solution water.

\section{MATERIAL AND METHODS}

Clinker ash of four different particle size distributions (No. 1 to No. 4) were used as specimens for the experiment. The particle size distribution curves of No. 1 to No. 4 are shown in Fig.1. The No.1 is the smallest particle size distribution and the No.4 is the largest particle size distribution.

Table 1 shows the physical and chemical properties of four specimens of clinker ash. The coefficient of permeability and the dry density were similar between four specimens and those ranges were $2.33 \times 10^{-2} \mathrm{~cm} / \mathrm{s}$ to $1.45 \times 10^{-1} \mathrm{~cm} / \mathrm{s}$ and $0.81 \mathrm{~g} / \mathrm{cm}^{3}$ to $0.93 \mathrm{~g} / \mathrm{cm}^{3}$, respectively. The specific gravity of all specimens was $2.19 \mathrm{~g} / \mathrm{cm}^{3}$. The values of $\mathrm{pH}$ and EC varied from 8.5 to 8.9 and from 0.1 $\mathrm{dS} / \mathrm{m}$ to $0.9 \mathrm{dS} / \mathrm{m}$, respectively. Total-nitrogen (T-N) included in the clinker ash before the experiment ranges from $2.3 \times 10^{-5} \mathrm{~kg} / \mathrm{kg}$ to $2.9 \times 10^{-5} \mathrm{~kg} / \mathrm{kg}$ and those values were very low.

Column experiment had been conducted in the laboratory (Temperature is $24^{\circ} \mathrm{C}$ and illumination is 550 lux) to examine the nitrogen purification (adsorption) capacity of clinker ash as shown in Fig. 2. Each specimen was poured into the PVC cylindrical column that has $44 \mathrm{~mm}$ in diameter and $350 \mathrm{~mm}$ in length. Two kinds of solution water, which contaminated by nitrate nitrogen 
with $10 \mathrm{mg} / \mathrm{L}$ and ammonium nitrogen with $10 \mathrm{mg} / \mathrm{L}$ supplied to each column at a flow rate of 100 to $200 \mathrm{~mL} / \mathrm{d}$ for 66 days. The drainage tube was lifted in the column upper part to make it a saturation state. The Total Nitrogen (Total-N) concentration of the water that flowed out of the column was measured every second or third day.

The nitrogen balance in each column during the experimental period was calculated by Eq. (1).

$$
L_{\text {in }}=L_{\text {out }}+L_{\text {ads }}
$$

where $L_{\text {out }}$ is nitrogen discharge from each column $(\mathrm{mg}), L_{\text {in }}$ is nitrogen supply to each column (mg), $L_{a d s}$ is nitrogen removed in each column (mg). In this study, we assumed that $L_{a d s}$ is equal to nitrogen adsorption on clinker ash.

\section{RESULTS AND DISCUSSION}

Figs. 3 and 4 shows the time series data of nitrogen concentration in drainage water in each column. In the column experiment with NH4-N solution water, all specimens recorded the lowest Total-N concentrations at $2.99 \mathrm{mg} / \mathrm{L}$ (No.1), $3.01 \mathrm{mg} / \mathrm{L}$ (No.2), $2.87 \mathrm{mg} / \mathrm{L}$ (No.3) and $2.98 \mathrm{mg} / \mathrm{L}$ (No.4) at 1st or 2nd day, respectively. From then on the concentration rose gradually, stabilizing in the range between $6 \mathrm{mg} / \mathrm{L}$ to $10 \mathrm{mg} / \mathrm{L}$. All specimens also recorded lower concentrations.
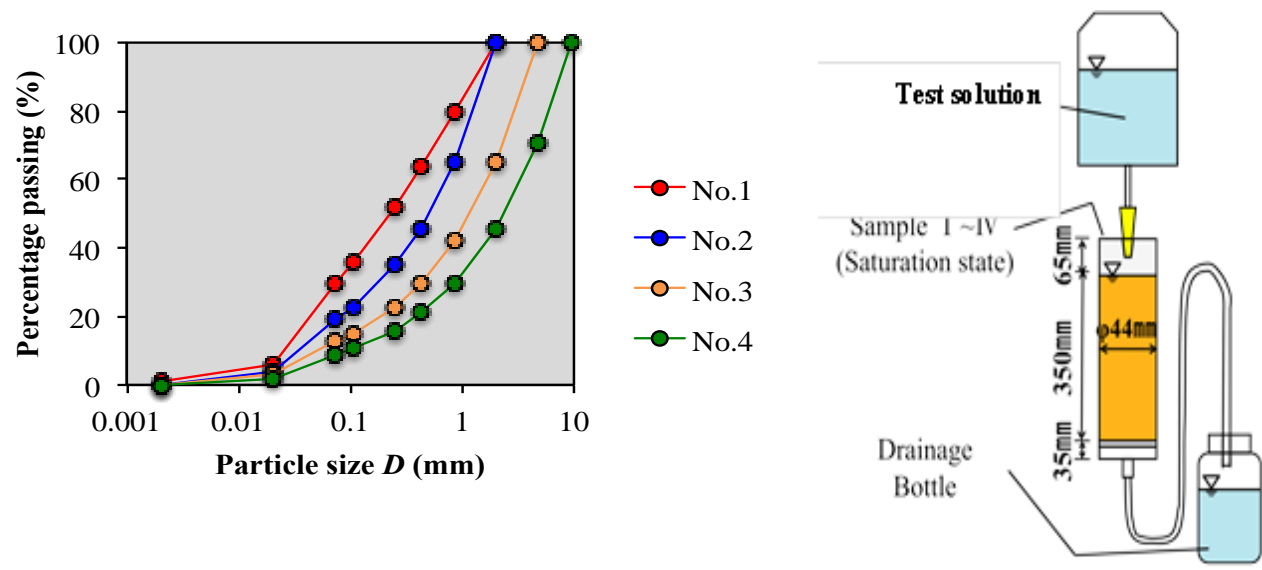

Fig.1 Particle size accumulation curve

Fig.2 Apparatus of column experiment

Total-N than that in the incoming solution $(10 \mathrm{mg} / \mathrm{L})$ throughout the experiment period, consistently demonstrating the presence of a water purification mechanism. It was clarified that clinker ash contained many fine particles seems to be effective in mitigating nitrogen pollution of water, because the Total-N concentration of No.1 and No.2 were lower than those of No.3 and No.4. 
Table 1 Physical and chemical properties of four specimen(s) of clinker ash

\begin{tabular}{|c|c|c|c|c|c|c|c|}
\hline \multirow[b]{2}{*}{$\mathrm{S}$} & \multicolumn{4}{|c|}{ Physical properties* } & \multicolumn{3}{|c|}{ Chemical properties** } \\
\hline & PS & $\begin{array}{c}\mathrm{CP} \\
\mathrm{k}(\mathrm{cm} / \mathrm{s})\end{array}$ & \begin{tabular}{|c} 
SG \\
$\rho_{\mathrm{s}} \quad\left(\mathrm{g} / \mathrm{cm}^{3}\right.$
\end{tabular} & $\begin{array}{c}\text { DD } \\
\rho_{d} \quad\left(g / \mathrm{cm}^{3}\right)\end{array}$ & $\mathrm{pH}_{1: 2.5}$ & $\begin{array}{l}\mathrm{EC}_{1: 5} \\
(\mathrm{dS} / \mathrm{m})\end{array}$ & $\begin{array}{l}\text { Total-N } \\
\left(\times 10^{-5}\right. \\
\mathrm{kg} / \mathrm{kg})\end{array}$ \\
\hline \begin{tabular}{|l|} 
No 1 \\
\end{tabular} & Finest & $1.09 \mathrm{E}-02$ & 2.19 & 0.93 & 8.5 & 0.3 & 2.4 \\
\hline No 2 & Fine & $2.33 \mathrm{E}-02$ & 2.19 & 0.89 & 8.6 & 0.2 & 2.6 \\
\hline \begin{tabular}{|l|} 
No 3 \\
\end{tabular} & Coarse & $1.45 \mathrm{E}-01$ & 2.19 & 0.88 & 8.9 & 0.2 & 2.9 \\
\hline No 4 & Coarsest & $5.43 \mathrm{E}-01$ & 2.19 & 0.81 & 8.9 & 0.1 & 2.3 \\
\hline
\end{tabular}

In the column experiment with NO3-N solution water (Fig.4), on the other hand, recorded the highest Total-N concentrations, at $5.0 \mathrm{mg} / \mathrm{L}$ (No.1), 9.28 $\mathrm{mg} / \mathrm{L} \mathrm{(No.2),} 6.26 \mathrm{mg} / \mathrm{L}$ (No.3) and $6.67 \mathrm{mg} / \mathrm{L} \mathrm{(No.4)} \mathrm{at} \mathrm{1st} \mathrm{day,} \mathrm{respectively.}$ Then, the Total-N concentration of water that ran through the column decreased to the smallest values by the 12 th day for all specimens.

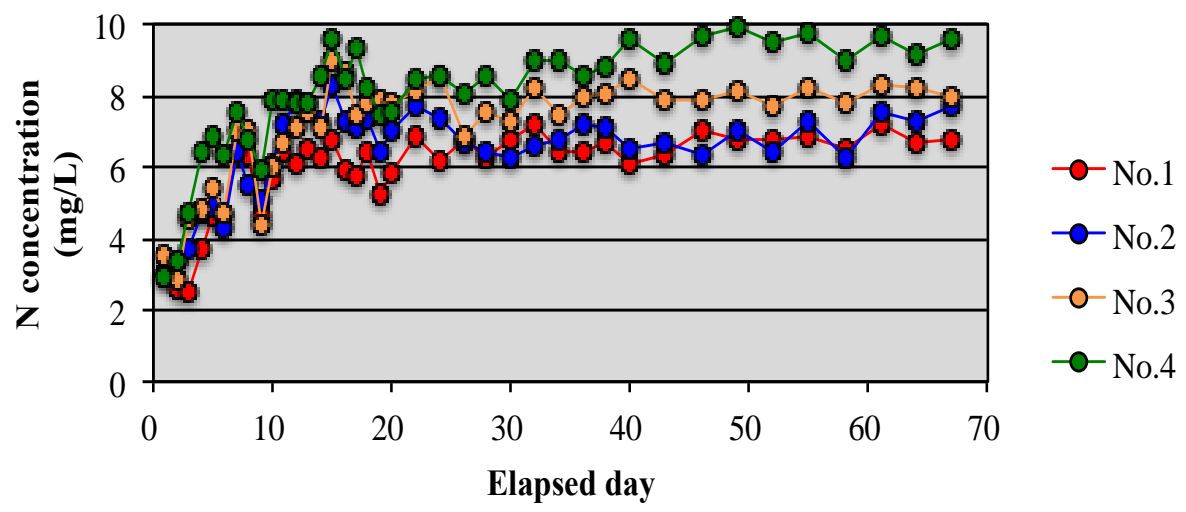

Fig. 3 Time series data of outflow nitrogen concentration

(The result of the column experiment with $10 \mathrm{mg} / \mathrm{L}$ of $\mathrm{NH}_{4}-\mathrm{N}$ solution water)

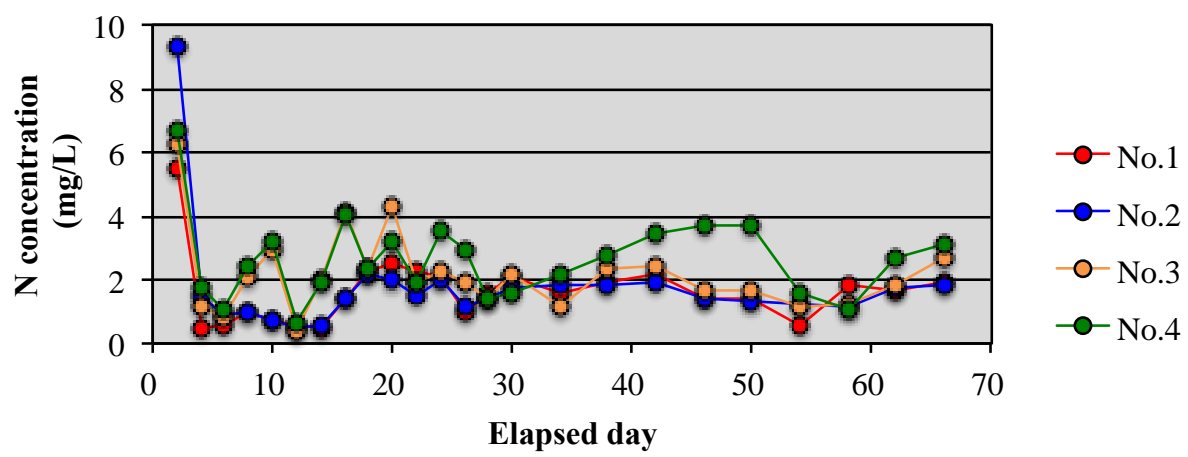

Fig.4 Time series data of outflow nitrogen concentration

(The result of the column experiment with $10 \mathrm{mg} / \mathrm{L}$ of $\mathrm{NO}_{3}-\mathrm{N}$ solution water) 
Table 2. Nitrogen balance of the column experiment for 66 days by using $10 \mathrm{mg} / \mathrm{L}$ of NH4-N and NO3-N solutions water as a test water

\begin{tabular}{|c|c|c|c|c|c|c|c|c|}
\hline \multirow{2}{*}{$\mathrm{NB}$} & \multicolumn{2}{|c|}{$\mathrm{NH}_{4}-\mathrm{N}$ solution water as a test water } & \multicolumn{3}{|c|}{$\mathrm{NO}_{3}-\mathrm{N}$ solution water as a test water } \\
\cline { 2 - 9 } & No 1 & No 2 & No 3 & No 4 & No 1 & No 2 & No 3 & No 4 \\
\hline $\boldsymbol{L}_{\text {in }}$ & 139.2 & 139.8 & 143.0 & 139.3 & 134.4 & 130.3 & 137.7 & 133.6 \\
$(\mathrm{mg})$ & $100 \%$ & $100 \%$ & $100 \%$ & $100 \%$ & $100 \%$ & $100 \%$ & $100 \%$ & $100 \%$ \\
\hline $\boldsymbol{L}_{\text {out }}$ & 87.1 & 93.1 & 107.1 & 118.7 & 21.7 & 22.6 & 34.9 & 37.0 \\
$(\mathrm{mg})$ & $63 \%$ & $67 \%$ & $75 \%$ & $85 \%$ & $16 \%$ & $17 \%$ & $25 \%$ & $28 \%$ \\
\hline $\boldsymbol{L}_{\text {ads }}$ & 52.1 & 46.6 & 35.8 & 20.6 & 112.7 & 107.8 & 102.8 & 96.6 \\
$(\mathrm{mg})$ & $37 \%$ & $33 \%$ & $25 \%$ & $15 \%$ & $84 \%$ & $83 \%$ & $75 \%$ & $72 \%$ \\
\hline
\end{tabular}

Calculation method of nitrogen balance:

Nitrogen balance defines as the equation; $L_{i n}=L_{o u t}+L_{a d s}$

$L_{\text {in }}$; nitrogen supply to a column (mg), $L_{\text {out }}$; nitrogen discharge from a column (mg),

$L_{a d s} ;$ nitrogen removed in each column (mg).

The Total-N concentration showed great variations. The changes in Total$\mathrm{N}$ concentration in the water of Nos. 1, 2 and 3 were great throughout the experiment period. The Total-N concentration values of the water after filtration for all specimens were much smaller than those before filtration $(10 \mathrm{mg} / \mathrm{L})$ throughout the 66 days of the experiment period. The above results demonstrate that the ratio of fine particle size of clinker ash is related to the performance of nitrogen mitigation. Furthermore, for all the specimens, the concentration of Total-N showed a steady level, even with increases in the elapse day. Based on the above finding, it was clarified that nitrate nitrogen was constantly removed for the long term.

Table 2 shows the nitrogen balance in each column for 66 days by using NH4-N solution water and NO3-N solution water. In the case of NH4-N solution water, the ratios of effluence (Lout/Lin) of each specimen were respectively 63\% (No.1), 67\% (No.2), 75\% (No.3) and 85\% (No.4). This illustrates that when the nitrogen solution passes through a column containing clinker ash, the nitrogen can remove from wastewater.

In the case of NO3-N solution water, the ratios of effluence (Lout/Lin) of each specimen were respectively $16 \%$ (No.1), $17 \%$ (No.2), $25 \%$ (No.3) and $28 \%$ (No.4). Those values were extremely lower than the result of NH4-N solution water. It was clarified that clinker ash was more effective in purifying NO3-N wastewater than NH4-N wastewater as an adsorption material.

\section{CONCLUSIONS}

The column experiment confirmed that nitrogen is removed by nitrogen adsorption of clinker ash. Namely, it was clarified that clinker ash has a great capacity to adsorb NO3-N and NH4-N. It was also found that fine-grained clinker ash is able to adsorb large amount of nitrogen. As the results, we concluded that clinker ash could be useful for nitrogen adsorbent of agricultural 
wastewater treatment. However, it is necessary to pay close attention to the particle size distribution of clinker ash when developing a water purification system using clinker ash. In addition, we have to clear the mechanism of nitrogen removal by clinker ash in high concentration nitrogen solution water, since the mechanism of nitrogen removal by clinker ash could not clarified in this study.

\section{ACKNOWLEDGEMENTS}

This research was supported by JSPS KAKENHI, Grant-in-Aid for Scientific Research (C), Grant Number 26450347, 2015 and the grant-aid from Tokyo University of Agriculture (TUA), Japan. The authors are also grateful for the research assistance provided by the students of the laboratory of Hydrostructure Engineering, Tokyo University of Agriculture.

\section{REFERENCES}

Japan Environmental Technology Association (JETA), (2005). Coal Ash Handbook, published by Japan fly ash association (in Japanese).

Mosier A., R., Syers, J., K., J., R., Freney. (2004). Agriculture and nitrogen cycle, Agriculture and the Nitrogen Cycle, p.3, published by ISLAND PRESS.

Okazawa, H., Yamamoto, D., Takeuchi, Y. (2010). Influences of Riparian Land Use on Nitrogen Concentration of River Water in Agricultural and Forest Watersheds of Northeastern Hokkaido, Japan, International Journal of Environmental and Rural Development, 1(2), 1-6.

Okazawa, H. and Fujikawa, T. (2014). NITROGEN ADSORPTION ABILITY IN CLINKER ASH AND UTILIZATION OF NITROGEN-ADSORBED CLINKER ASH TO PROMOTE VEGETATION GROWTH, Agriculture and Forestry, 60(4), 15-20.

World coal association (2015): http://www.worldcoal.org/coal/uses-of-coal/coalelectricity/

Yoshinaga, I., Miura, A., Hamada, K., Shiratani, E. (2007). Runoff Nitrogen from a Large Size Paddy Field during a Crop Period, Agricultural Water Management, 87, 217-222.

Yamamoto, H., Okazawa, H., Ohtaka, Y., Takeuchi, Y. (2011). Fundamental Study on Nitrogen Removal from Paddy Drainage Using Clinker Ash, International Journal of Environmental and Rural Development, 2(1), 54-58. 